\title{
Microarray-based gene expression profiling of peripheral blood mononuclear cells in dairy cows with experimental hypocalcemia and milk fever
}

\author{
K. Sasaki, ${ }^{\star} \dagger \ddagger$ N. Yamagishi, ${ }^{,} \dagger^{1}$ K. Kizaki, ${ }^{\dagger} \dagger$ K. Sasaki,‡ B. Devkota, $† \S$ and K. Hashizume ${ }^{*} \dagger$ \\ *United Graduate School of Veterinary Sciences, Gifu University, Gifu, Gifu 501-1193, Japan \\ †Cooperative Department of Veterinary Medicine, Iwate University, Morioka, Iwate 020-8550, Japan \\ †lwate Veterinary Hospital, Iwate-machi, Iwate 028-4307, Japan \\ $\S B i o t e c h n o l o g y$ Center, Agriculture and Forestry University, Chitwan, Nepal
}

\section{ABSTRACT}

Although a molecular diagnostic assay using clinically accessible tissue, such as blood, would facilitate evaluation of disease conditions in humans and animals, little information exists on microarray-based gene expression profiling of circulating leukocytes from clinically hypocalcemic cows. Therefore, peripheral blood mononuclear cells from dairy cows with experimentally induced hypocalcemia or spontaneous milk fever were subjected to oligo-microarray analysis to identify specific biomarker genes. In experimental hypocalcemia induced by a 4 -h infusion of $10 \%$ disodium EDTA (n $=4), 32$ genes were significantly up- or downregulated compared with control treatment (4-h infusion of $11 \%$ calcium EDTA; $\mathrm{n}=4$ ). In cows with milk fever (n $=8$ ), 98 genes were expressed differentially (either up- or downregulated) compared with healthy parturient cows $(\mathrm{n}=5)$. From these data, the following 5 genes were selected as being strongly related to both experimental hypocalcemia and milk fever: protein kinase (cAMP-dependent, catalytic) inhibitor $\beta$ (PKIB); DNA-damage-inducible transcript 4 (DDIT4); period homolog 1 (PER1); NUAK family, SNF1-like kinase, 1 (NUAK1); and expressed sequence tag (BI537947). Another gene (neuroendocrine secretory protein 55, NESP55) was also determined to be specific for milk fever, independently of hypocalcemia. The mRNA expression of these 6 genes in milk fever cases was verified by quantitative real-time reverse-transcription PCR and was significantly different compared with their expression in healthy parturient cows. In the present study, the selected genes appeared to be candidate biomarkers of milk fever because the continuous interactions between blood cells and the entire body suggest that subtle intracellular changes occur in association with disease. However, before any genomic biomarkers are incorporated into clinical evaluation of the disease,

Received May 21, 2013.

Accepted September 16, 2013.

${ }^{1}$ Corresponding author: yamagisi@iwate-u.ac.jp the effect of hypocalcemia on the mRNA expression of these genes in the tissues that regulate calcium homeostasis in dairy cows should be determined.

Key words: dairy cow, microarray-based gene expression profiling, milk fever, peripheral blood mononuclear cell (PBMC)

\section{INTRODUCTION}

Milk fever is an afebrile disease of primarily multiparous cows that occurs around the time of parturition. Affected cows show characteristic clinical signs, such as progressive neuromuscular dysfunction with flaccid paralysis, recumbency, circulatory collapse, cold extremities, depressed consciousness, and coma (Goff, 2009). The biochemical characteristic of this disease is severe hypocalcemia, which most likely explains the associated clinical signs (Goff, 2009). Investigation of this disease has focused on blood Ca concentrations around parturition because of the close relationship between hypocalcemia and the onset of milk fever (Goff, 2009). Several other blood parameters, such as phosphorus, magnesium, parathyroid hormone, calcitonin, 1,25-dihydroxyvitamin $\mathrm{D}_{3} \quad\left[1,25(\mathrm{OH})_{2} \mathrm{D}_{3}\right]$, and some bone metabolic markers associated with the regulation of $\mathrm{Ca}$ metabolism have also been considered in an attempt to further understand $\mathrm{Ca}$ homeostasis and the pathophysiology of milk fever (Liesegang et al., 1998; Larsen et al., 2001; Kim et al., 2010).

Microarray technology has recently been shown to be a useful tool for simultaneously measuring the expression of thousands of genes and for clarifying the molecular mechanisms of many diseases in humans and animals. In cattle, this molecular genomic approach has been utilized to study the pathophysiology of lameness (Almeida et al., 2007), ketosis (Loor et al., 2007), mastitis (Lutzow et al., 2008), brisket disease (Newman et al., 2011), and growth retardation (Ishida et al., 2013). In most experiments, this technique was applied to genes within various body tissues (e.g., liver, kidney, intestine, mammary gland, or lymph node) from diseased animals, whereas other studies have used genes from 
circulating leukocytes to identify biomarkers of pathophysiological status (Almeida et al., 2007; Newman et al., 2011; Ishida et al., 2013). Although still in the early stages of research and development, genomic biomarkers can provide comprehensive insight into pathophysiological processes as well as more precise prediction of disease outcomes not previously attainable using protein or biochemical biomarkers (Ginsburg and Haga, 2006). In addition, a molecular diagnostic assay using clinically accessible tissue, such as blood, would facilitate evaluation of disease conditions of animals (Almeida et al., 2007). To our knowledge, little information is available on microarray-based gene expression profiles of circulating leukocytes from hypocalcemic dairy cows with milk fever.

In the present study, peripheral blood mononuclear cells (PBMC) from dairy cows with experimentally induced hypocalcemia or spontaneous milk fever were subjected to oligo-microarray analysis. Genes that showed common altered expressions in cows with experimentally induced hypocalcemia and spontaneous milk fever were then assessed by quantitative real-time reverse-transcription PCR (q-PCR). The aim of this study was to identify potential biomarkers of hypocalcemia and milk fever in PBMC of dairy cows by microarray-based gene-expression profiling.

\section{MATERIALS AND METHODS}

This animal experimental protocol was approved by the Iwate University Laboratory Animal Care and Use Committee.

\section{Experimentally Induced Hypocalcemia}

Four healthy, nonpregnant, nonlactating, ovariectomized Holstein cows (6.3-8.3 yr of age, $520-665 \mathrm{~kg}$ of BW) were used. A bilateral ovariectomy was performed in each cow by lateral laparotomy at least 3 mo before the experiment to exclude the effects of gonadal steroid hormones (Devkota et al., 2012). The cows were housed individually and loose-tied at least $4 \mathrm{wk}$ before the start of the experiment. The cows were fed $5 \mathrm{~kg}$ of grass hay and $0.5 \mathrm{~kg}$ of concentrate twice daily and had access to tap water ad libitum.

One hundred grams of disodium EDTA $\left(\mathrm{Na}_{2}-\mathrm{EDTA}\right.$; Kanto Chemical, Tokyo, Japan) was dissolved in 1,000 $\mathrm{mL}$ of endotoxin-free sterile distilled water and adjusted to $\mathrm{pH} 7.0$ with sodium hydroxide. One hundred ten grams of Ca-EDTA (Dojindo, Kumamoto, Japan) was dissolved in 1,000 $\mathrm{mL}$ of endotoxin-free sterile distilled water and adjusted to $\mathrm{pH} 7.0$ with hydrochloric acid. The solutions were transferred to a sterile container through a 0.2- $\mu \mathrm{m}$ filter (Sterifix; Forte Grow Medical, Tochigi, Japan) to remove bacteria.

The experiment was performed according to a $2 \times$ 2 crossover design with 2 -wk intervals. In brief, an intravenous catheter (UK catheter kit, 14 gauge, $30 \mathrm{~cm}$; Unitika, Osaka, Japan) was inserted into each jugular vein $1 \mathrm{~d}$ before the EDTA infusion to alleviate the stress associated with the infusion and blood collection. Cows were infused with either $\mathrm{Na}_{2}$-EDTA solution (hypocalcemic treatment) or Ca-EDTA solution (control treatment) at a rate of $0.25 \mathrm{mmol} / \mathrm{kg}$ per minute for $4 \mathrm{~h}$, based on previous studies (Jørgensen et al., 1999; Mellau et al., 2004). The animals were monitored for clinical signs of hypocalcemia (e.g., dry nose, staggering, astasia, reduced ruminal activity, increased heart rate, increased respiratory frequency, sweating, and ear coldness). The infusion was suspended temporarily when ataxia was observed, and was resumed when the affected cow regained a standing posture.

Heparinized blood collection was performed immediately before infusion ( $0 \mathrm{~h}$; pretreatment) and at 1, 2, 3, $4,6,8,10,12,18$, and $24 \mathrm{~h}$ after the start of infusion. All blood samples were placed on ice and transported to the laboratory within $30 \mathrm{~min}$. All blood samples were used to measure plasma Ca levels, and blood at 0, 4, and $24 \mathrm{~h}$ was used for PBMC gene expression analysis.

\section{Spontaneous Milk Fever}

A total of 13 Holstein dairy cows, including 8 parturient cows (5.2-8.7 yr of age) diagnosed with milk fever within $2 \mathrm{~d}$ after parturition and 5 clinically healthy parturient cows (group C; 5.7-8.5 yr of age) within 2 $\mathrm{d}$ after parturition, were used. The clinical diagnosis of milk fever was determined based on the clinical history and presence of clinical signs characteristic of hypocalcemia, as reported previously (Sasaki et al., 2013). All cows showed clinical hypocalcemia with $<1.4$ $\mathrm{mmol} / \mathrm{L}$ of $\mathrm{Ca}$ in the blood samples obtained before the first treatment and were treated with an intravenous infusion of $20 \%$ Ca borogluconate solution $(500 \mathrm{~mL})$. The milk fever cases were divided into 2 categories according to the response to the first Ca treatment: the immediate-response group, in which cows could stand within $1 \mathrm{~d}$ after a single Ca treatment (group A, $\mathrm{n}=$ 4 ), and the group requiring further treatment after $1 \mathrm{~d}$ (group $\mathrm{B}, \mathrm{n}=4$ ).

Heparinized blood samples were collected via the jugular vein immediately before the first Ca treatment in groups $\mathrm{A}$ and $\mathrm{B}$, and within $2 \mathrm{~d}$ postpartum in group $\mathrm{C}$, for plasma biochemistry and gene expression evaluation. All samples were placed on ice and transported to the laboratory within $3 \mathrm{~h}$. 


\section{Plasma Biochemistry}

Blood was centrifuged at $1,000 \times g$ for $15 \mathrm{~min}$ at room temperature, and the plasma was stored at $-50^{\circ} \mathrm{C}$ until analysis. Plasma $\mathrm{Ca}$, inorganic phosphorus, $\mathrm{Mg}$, glucose, BUN, total cholesterol, aspartate aminotransferase, and $\gamma$-glutamyl transferase were measured using an Accute TBA-40FR autoanalyzer (Toshiba, Tokyo, Japan). Plasma concentrations of intact parathyroid hormone (iPTH) and $1,25(\mathrm{OH})_{2} \mathrm{D}_{3}$ were measured by electrochemiluminescence immunoassay (Elecsys PTH Kit; Roche Diagnostics, Mannheim, Germany) and radioimmunoassay $\left(1,25(\mathrm{OH})_{2}\right.$ D RIA; TFB, Tokyo, Japan). The intra- and interassay coefficients of variances $(\mathbf{C V})$ for the iPTH immunoassay were 2.8 and $4.5 \%$, respectively, and for $1,25(\mathrm{OH})_{2}$ D RIA were 4.6 and $11.4 \%$, respectively.

\section{PBMC Isolation and RNA Extraction}

The PBMC were isolated by density centrifugation on a Histopaque-1077 (Sigma Diagnostics, St. Louis, MO) according to the manufacturer's instructions. Total RNA was extracted from the PBMC with TRIzol (Invitrogen, Carlsbad, CA) according to the manufacturer's instructions. Extracted total RNA was stored at $-80^{\circ} \mathrm{C}$ until analysis. Total RNA was tested and confirmed for quality and quantity using either a capillary electrophoresis system (2100 Bioanalyzer, Agilent Technologies, Santa Clara, CA) or spectrophotometer (NanoDrop ND-1000, Thermo Fisher Scientific, Waltham, MA).

\section{Microarray Analysis}

A customized bovine oligonucleotide microarray comprising 15,268 unique genes (GPL9284; Agilent Technologies) was used to detect genes expressed in PBMC by one-color microarray analysis (Kizaki et al., 2013). Fluorescently labeled (Cy3) complementary (c) RNA probes were hybridized and washed using the Gene Expression Hybridization Kit and Gene Expression Wash Pack Kit (Agilent Technologies). The arrays were scanned using an Agilent Microarray Scanner (Agilent Technologies). Feature Extraction ver. 9.1 (Agilent Technologies) was used to process microarray images, align spots, and finally create raw numerical total spot intensity data.

The microarray data from each sample were imported into GeneSpring 12.0 (Agilent Technologies) for use in the software's normalization algorithm and for candidate gene detection. Normalization was performed by dividing each measurement of each array by the median of all measurements in that array (per- chip normalization). The analysis comprised 3 parts. The first involved identification of specific genes with altered expression in experimentally induced hypocalcemia. The second involved identification of specific genes in spontaneous milk fever. The final part was determination of the genes showing altered expression in both experimental hypocalcemia and milk fever. The Gene Expression Omnibus (GEO; http://www.ncbi. nlm.nih.gov/geo/query/acc.cgi) accession numbers are as follows: Platform: GPL9284; samples: GSM1140359 to GSM1140395; series: GSE46901.

\section{Quantitative Real-Time Reverse Transcription-PCR}

The genes with altered expression in both experimentally induced hypocalcemia and spontaneous milk fever were analyzed using the total RNA of groups A, $\mathrm{B}$, and $\mathrm{C}$ by $\mathrm{q}-\mathrm{PCR}$. Total RNA $(1 \mu \mathrm{g})$ was converted into first-strand cDNA using the ImProm-II Reverse Transcription System (Promega, Madison, WI). Primers (Table 1) were designed using the Primer Express software (Applied Biosystems). All PCR reactions were performed with a cDNA template of $0.5 \mu \mathrm{L}$ (50 ng/ $\mu \mathrm{L}), 0.5 \mu \mathrm{L}$ of forward primer $(5 \mu M), 0.5 \mu \mathrm{L}$ of reverse primer $(5 \mu M), 12.5 \mu \mathrm{L}$ of Power SYBR Green PCR Master Mix (Applied Biosystems), and 11.0 $\mu \mathrm{L}$ of nuclease-free water. Thermal cycling conditions included 1 cycle at $95^{\circ} \mathrm{C}$ for $10 \mathrm{~min}$ and 40 cycles at $95^{\circ} \mathrm{C}$ for $15 \mathrm{~s}$ and $60^{\circ} \mathrm{C}$ for $1 \mathrm{~min}$, in a StepOne Plus RT-PCR system (Applied Biosystems). Results were recorded as relative gene expression changes after normalizing to GAPDH, $\beta$-actin, or ribosomal protein S9 genes expression by the $2^{-\Delta \Delta \mathrm{Ct}}$ method (Livak and Schmittgen, 2001). We observed no significant difference in the data normalizing to GAPDH compared with the other 2 genes (data not shown). It is known that $G A P D H$ is a stable reference gene in PBMC and could be used as an index to normalize data (Robinson et al., 2007). Therefore, the present study normalized the data to GAPDH.

\section{Statistical Analysis}

All numerical data are expressed as means \pm standard deviations (SD). The plasma biochemistry and background information of the clinical cases data were analyzed using the Sigmaplot software, version 12.0 (Systat Software, San Jose, CA). First, the values were checked for normal distribution by KolmogorovSmirnov normality tests. Next, in the experimentally induced hypocalcemia cows, the change in the plasma Ca concentration in each treatment group was analyzed by one-way repeated-measures (RM) ANOVA and Dunnett's test, using the pretreatment value as the control. To compare the values between 2 treatments 
Table 1. Primers used for real-time reverse transcription-PCR

\begin{tabular}{llll}
\hline Gene $^{1}$ & Forward & Reverse & $\begin{array}{c}\text { Product size } \\
(\mathrm{bp})\end{array}$ \\
\hline PKIB & TTCACCCAAAATGACGGATGT & CCGTTGAACCCTGGATGTCT & 100 \\
DDIT4 & GATAACGCCCCCATGTCAGA & TCAGGTGGCTGTTGTCAGTTT & 105 \\
PER1 & GAGCACGTCACATCTGAGTACACA & TAGACGATGCGGCTGTCA & 83 \\
NUAK1 & TGAAAATGCAAGTGCTCTC & AGGAATGATACCATGCCAGTA & 199 \\
BI537947 & GAGTGCCACACCACGCCTAT & TCACAGAGGGAACAGCACTGA & 103 \\
NESP55 & TTTTTATGCTGCACAACACGAT & GCCACAAATGTTCCTCTCTCTT & 116 \\
GAPDH & AAGGCCATCACCATCTTCCA & CCACTACATACTCAGCACCAGCAT & 76 \\
\hline
\end{tabular}

${ }^{1} P K I B=$ protein kinase (cAMP-dependent, catalytic) inhibitor $\beta$; DDIT4 = DNA-damage-inducible transcript $4 ;$ PER1 = period homolog 1 ; NUAK1 = NUAK family, SNF1-like kinase, 1; BI537947 = expressed sequence tag; NESP55 = neuroendocrine secretory protein 55.

at each time point, 2-way RM ANOVA (treatment $x$ time) and Tukey-Kramer's multiple comparison tests were carried out. In the spontaneous milk fever group, the data were analyzed by ANOVA and Tukey-Kramer's multiple comparison tests or by the Kruskal-Wallis test and Dunn's multiple comparison tests to assess differences among the 3 groups after the normality tests.

Microarray data were analyzed using GeneSpring 12.0 (Agilent Technologies) and Sigmaplot (Systat Software) software. In the experimental hypocalcemia group, the differences in gene expression between each time point $(0,4$, and $24 \mathrm{~h})$ within each treatment group were assessed by the Friedman RM ANOVA on ranks and Tukey-Kramer's multiple comparison test. Student's $t$-test was used to compare the difference in expression levels between 2 groups at the same time point. In the spontaneous milk fever group, one-way ANOVA and Tukey's honestly significant difference multiple-comparison test were used to assess differences in gene expression levels among the 3 groups. Fold changes were calculated to identify the direction of change in gene expression by comparison of the postinfusion (4 and $24 \mathrm{~h}$ ) levels with the pretreatment $(0 \mathrm{~h})$ levels in the experimental hypocalcemia cows, and by comparison of the expression of milk fever cows (groups $\mathrm{A}$ and $\mathrm{B}$ ) with that of group $\mathrm{C}$ in the spontaneous milk fever cows. The cut-off value of fold change was set at $\geq 2.0$ or $\leq 0.5$.

The q-PCR data in cows with spontaneous milk fever were analyzed using the Sigmaplot software (Systat Software). To detect differences among the 3 groups, the values were analyzed by ANOVA and Tukey-Kramer's multiple-comparison tests or the Kruskal-Wallis test and Dunn's multiple-comparison tests after normality tests. Significance for all tests was set at $P<0.05$.

\section{RESULTS}

\section{Clinical and Plasma Biochemical Parameters in Experimentally Induced Hypocalcemia}

Figure 1 shows the changes in plasma Ca concentrations after infusion of $\mathrm{Na}_{2}$-EDTA or Ca-EDTA. In cows that underwent hypocalcemic treatment, specific clinical signs were detected, and the time in which cows became recumbent after $\mathrm{Na}_{2}$-EDTA infusion varied from 2.5 to $4 \mathrm{~h}$. The clinical signs of hypocalcemia disappeared 8 $\mathrm{h}$ after the start of $\mathrm{Na}_{2}$-EDTA infusion. A 2-way RM ANOVA examined the dependence of plasma Ca concentration on treatment and time; both were significant factors $(P<0.01)$ and interacted significantly $(P<$ 0.01). Plasma Ca concentrations decreased immediately after the start of $\mathrm{Na}_{2}$-EDTA infusion and reached the minimum $(0.9 \pm 0.1 \mathrm{mmol} / \mathrm{L})$ at $2 \mathrm{~h}$. Calcium concentrations showed significantly lower levels from 1 to $10 \mathrm{~h}$ $(P<0.05$ or 0.01$)$. In cows that underwent the control treatment, plasma $\mathrm{Ca}$ concentration was unchanged and no clinical signs of hypocalcemia were detected.

\section{Clinical and Plasma Biochemical Parameters in Spontaneous Milk Fever}

Table 2 depicts the parity, day of onset, and plasma biochemical parameters at the first treatment in milk fever cases (groups A and B) and within $2 \mathrm{~d}$ postpartum in clinically healthy cows (group C). Cows in groups A and $\mathrm{B}$ showed significantly lower plasma $\mathrm{Ca}$ and inorganic $\mathrm{P}$ concentrations and higher iPTH levels than those of group C. We observed no significant differences in the other parameters among the 3 groups.

\section{Microarray Data of Differential Gene Expression in PBMC of Cows with Experimentally Induced Hypocalcemia and Spontaneous Milk Fever}

In cows with experimental hypocalcemia, 98 genes were differentially expressed (up- or downregulated) at $4 \mathrm{~h}$ in cows that underwent hypocalcemic treatment compared with those at 0 and $24 \mathrm{~h}$. In cows undergoing the control treatment, 364 genes were differently expressed at 4 or $24 \mathrm{~h}$ compared with those at $0 \mathrm{~h}$. Then, 13 of 98 genes that differed in cows with experimental hypocalcemia were excluded from the data because they also varied significantly in cows with control treatment. The remaining genes were examined for differences in 
Table 2. Clinical information and blood biochemical parameters in milk fever (groups A and B) and clinically healthy parturient cows (group C)

\begin{tabular}{|c|c|c|c|}
\hline Item & $\begin{array}{c}\text { Group A } \\
(\mathrm{n}=4)\end{array}$ & $\begin{array}{c}\text { Group B } \\
(\mathrm{n}=4)\end{array}$ & $\begin{array}{c}\text { Group C } \\
(\mathrm{n}=5)\end{array}$ \\
\hline Parity & $4.8 \pm 1.0$ & $4.0 \pm 0.8$ & $3.8 \pm 0.8$ \\
\hline Day of onset (d) & $1.0 \pm 0.8$ & $0.8 \pm 0.5$ & $0.6 \pm 0.5$ \\
\hline \multicolumn{4}{|l|}{ Plasma biochemistry } \\
\hline $\mathrm{Ca}(\mathrm{mmol} / \mathrm{L})$ & $0.9 \pm 0.1^{\mathrm{a}}$ & $1.1 \pm 0.2^{\mathrm{a}}$ & $2.4 \pm 0.1^{\mathrm{b}}$ \\
\hline Inorganic $\mathrm{P}(\mathrm{mmol} / \mathrm{L})$ & $0.7 \pm 0.4^{\mathrm{a}}$ & $0.6 \pm 0.4^{\mathrm{a}}$ & $1.5 \pm 0.1^{\mathrm{b}}$ \\
\hline $\mathrm{Mg}(\mathrm{mmol} / \mathrm{L})$ & $0.8 \pm 0.0$ & $1.0 \pm 0.1$ & $1.0 \pm 0.2$ \\
\hline Glucose (mmol/L) & $4.9 \pm 1.8$ & $4.7 \pm 2.2$ & $3.7 \pm 0.7$ \\
\hline $\mathrm{BUN}(\mathrm{mmol} / \mathrm{L})$ & $5.3 \pm 2.0$ & $4.3 \pm 0.8$ & $4.1 \pm 1.0$ \\
\hline Total cholesterol $(\mathrm{mmol} / \mathrm{L})$ & $1.5 \pm 0.2$ & $1.7 \pm 0.4$ & $1.8 \pm 0.3$ \\
\hline Aspartate aminotransferase (U/L) & $85.4 \pm 18.6$ & $95.5 \pm 17.1$ & $96.8 \pm 34.7$ \\
\hline$\gamma$-Glutamyl transferase $(\mathrm{U} / \mathrm{L})$ & $17.2 \pm 4.8$ & $14.4 \pm 5.7$ & $29.4 \pm 11.8$ \\
\hline Intact parathyroid hormone $(\mathrm{pg} / \mathrm{mL})$ & $346.0 \pm 122.4^{\mathrm{a}}$ & $606.0 \pm 635.3^{\mathrm{a}}$ & $71.6 \pm 48.0^{\mathrm{b}}$ \\
\hline 1,25 -Dihydroxyvitamin $\mathrm{D}_{3}(\mathrm{pg} / \mathrm{mL})$ & $117.0 \pm 29.0$ & $108.0 \pm 43.3$ & $95.0 \pm 37.0$ \\
\hline
\end{tabular}

${ }^{\mathrm{a}, \mathrm{b}}$ Values with different superscripts in each parameter indicate significant differences $(P<0.05)$.

the expression levels at $4 \mathrm{~h}$ between hypocalcemic and control treatments. A total of 32 genes were identified as having altered expression upon hypocalcemic treatment (Table 3).

Figure 2 shows a Venn diagram of the number of genes differentially expressed among the 3 groups: milk fever (groups A and B) and clinically healthy parturient (group C) cows. Seven hundred and three genes were expressed differentially between groups $\mathrm{A}$ and $\mathrm{C}$, and 158 genes between groups B and C. Ninety-eight genes were determined to be specific to groups $\mathrm{A}$ and $\mathrm{B}$ (Table 4). Moreover, one of these genes, neuroendocrine

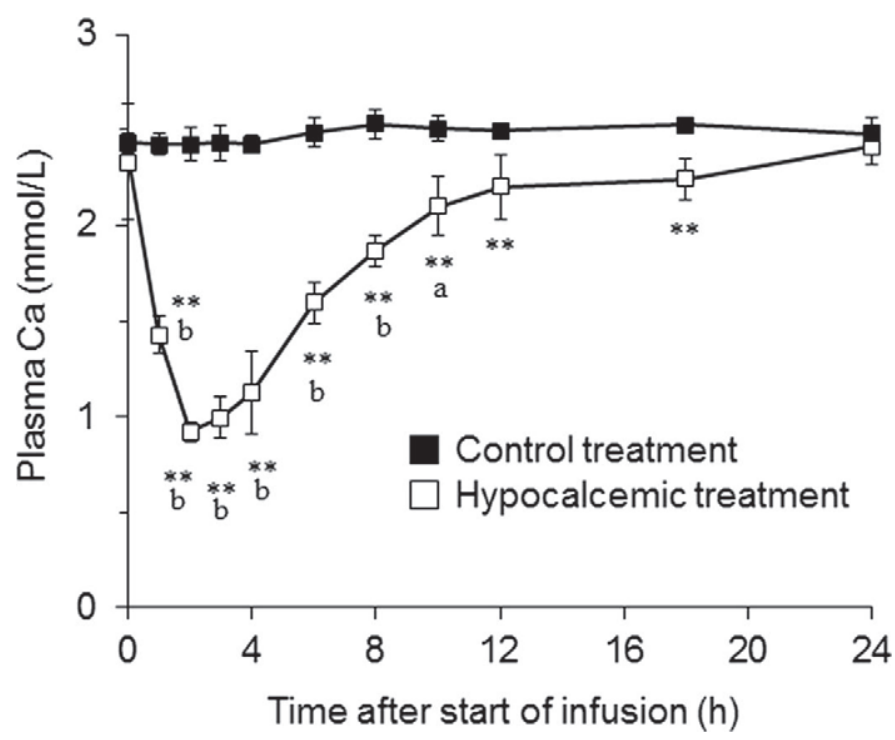

Figure 1. Changes in plasma Ca concentrations in cows receiving intravenous infusion of $\mathrm{Na}_{2}$-EDTA (hypocalcemic treatment) or CaEDTA (control treatment) for $4 \mathrm{~h}$. Significant differences from the pretreatment value are indicated by letters $(\mathrm{a}, P<0.05$ and $\mathrm{b}, P<$ $0.01)$ within each group, and by asterisks $\left({ }^{* *} P<0.01\right)$ between treatments at the same time point. secretory protein 55 (NESP55), showed differential expression between groups A and B (Figure 2).

Figure 3 shows a Venn diagram of the number of genes differentially expressed between the experimental hypocalcemia and milk fever cows. Milk fever cows exhibited significantly different expression of 98 genes compared with clinically healthy parturition cows, and expression of 32 genes was significantly different between the hypocalcemic and control treatments. Five genes were common to both conditions: protein kinase (cAMP-dependent, catalytic) inhibitor $\beta$ (PKIB); DNA-damage-inducible transcript 4 (DDIT4); period homolog 1 (PER1); NUAK family, SNF1-like kinase, 1 (NUAK1); and expressed sequence tag (BI537947).

\section{Transcriptional Expression of Selected Genes in PBMC of Milk Fever Cows}

The q-PCR confirmed that the PKIB, DDIT4, PER1, NUAK1, and BI537947 genes were commonly upregulated in both groups A and B compared with group C (Figure 4). However, NESP55 was downregulated in both groups A and B compared with group C.

\section{DISCUSSION}

Peripheral blood mononuclear cells in healthy adult cows account for a major portion (63-70\%) of all circulating leukocytes (Morris, 2009). Kimura et al. (2006) reported decreased intracellular $\mathrm{Ca}^{2+}$ stores in PBMC of dairy cows before parturition and development of hypocalcemia. They suggested that systemic Ca stress precedes measurable hypocalcemia in cows that will develop milk fever. Other studies showed that hypocalcemia in rats blunts the release of intracellular $\mathrm{Ca}^{2+}$ (Gascon-Barré et al., 1994), and suggested that the extracellular fluid $\mathrm{Ca}^{2+}$ status is a primary determinant 
Table 3. Microarray data of 32 genes whose expression in peripheral blood mononuclear cells of experimentally induced hypocalcemic cows at $4 \mathrm{~h}$ was significantly different from that of the pretreatment time

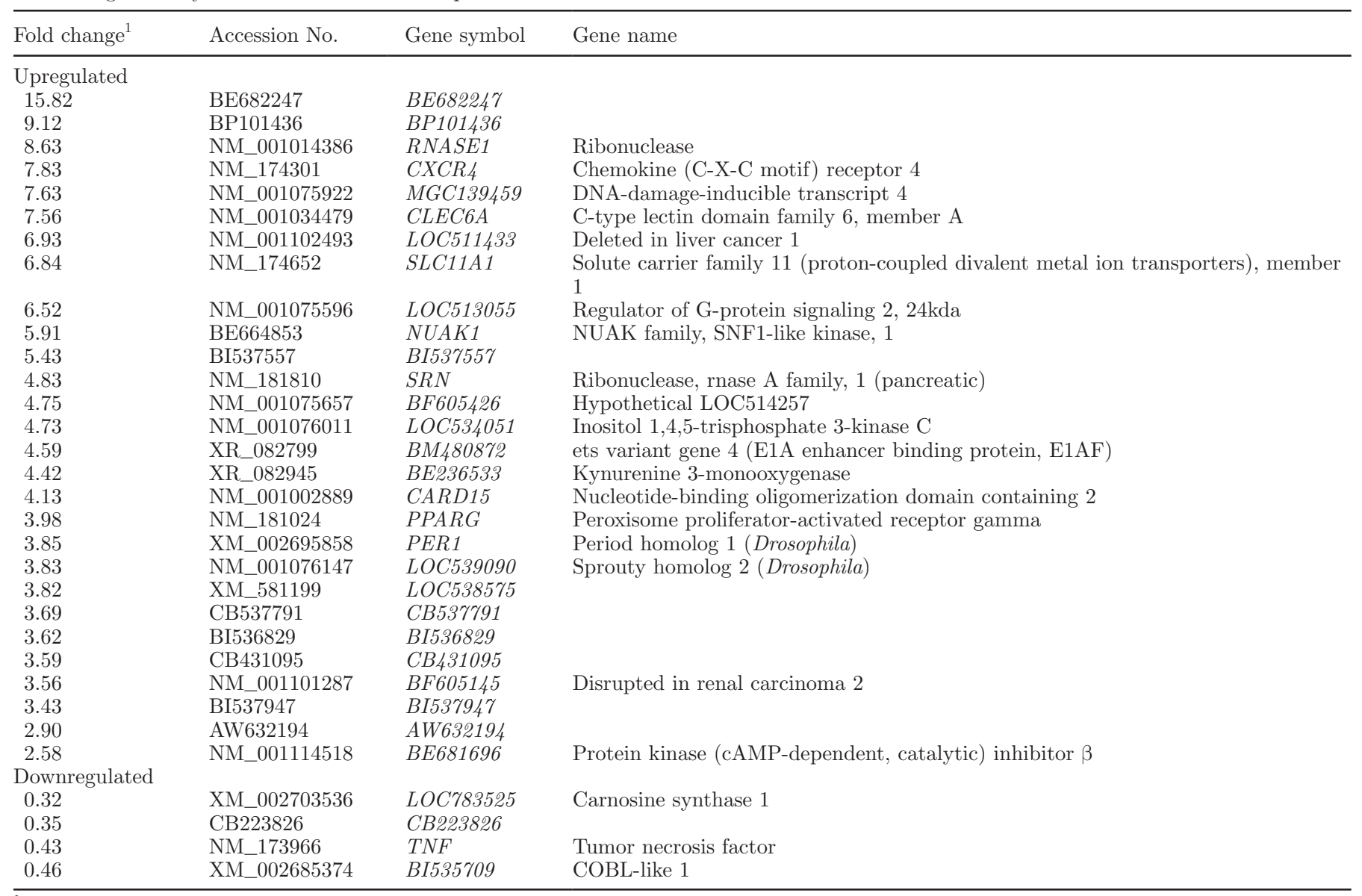

${ }^{1}$ Fold change of $4 \mathrm{~h}$ compared with pretreatment in induced hypocalcemia.

of the intracellular $\mathrm{Ca}^{2+}$ status (Mailhot et al., 2000), which is the main regulator for intracellular signaling. Therefore, we evaluated the change in mRNA levels in PBMC of cows with milk fever.

In the present study, experimental hypocalcemia was induced by $\mathrm{Na}_{2}$-EDTA infusion, and its clinical signs and changes in plasma $\mathrm{Ca}$ concentrations resembled those in previous reports (Jørgensen et al., 1999; Mellau et al., 2004). Infusion of $\mathrm{Na}_{2}$-EDTA results in complex binding with divalent cations, such as $\mathrm{Ca}^{2+}$, and nearly $100 \%$ of the complex Ca-EDTA is excreted in the kidneys by glomerular filtration, with a clearance ratio similar to that of inulin (Jørgensen et al., 1999). Therefore, we used Ca-EDTA infusion as a control treatment to emphasize the effect of $\mathrm{Ca}$ depletion without the influence of a chelating agent.

Milk fever was associated with marked hypocalcemia and hypophosphatemia, as reported previously (Goff, 2009; Sasaki et al., 2013). Although plasma iPTH concentrations in cows with milk fever (groups A and B) were higher than those in clinically healthy parturient cows (group C), as described elsewhere (Horst et al., 1997), plasma $1,25-(\mathrm{OH})_{2} \mathrm{D}_{3}$ levels were not significantly different among the 3 groups (around 100 $\mathrm{pg} / \mathrm{mL}$ ). Parathyroid hormone is released in response to reductions in blood Ca (Brown et al., 1995), and it stimulates bone Ca mobilization, renal tubular $\mathrm{Ca}$ reabsorption, and renal 1,25- $(\mathrm{OH})_{2} \mathrm{D}_{3}$ synthesis (Goff, 2008). The plasma $1,25-(\mathrm{OH})_{2} \mathrm{D}_{3}$ concentration increases to more than $100 \mathrm{pg} / \mathrm{mL}$ in healthy parturient cows (Horst et al., 1994). Therefore, the blood samples were collected during an early period of hypocalcemia associated with activated PTH secretion and unstimulated $1,25-(\mathrm{OH})_{2} \mathrm{D}_{3}$ synthesis in our case.

In the present study, the microarray-based gene expression profiling and q-PCR analysis showed that expression of the PKIB, DDIT4, PER1, NUAK1, and $B I 537947$ genes in PBMC were significantly upregulated in cows with milk fever (groups A and B) compared with clinically healthy parturient cows (group C).

Protein kinase (cAMP-dependent, catalytic) inhibitor $\beta$ (PKIB) is a member of the cAMP-dependent protein kinase (PKA) inhibitor family (Zheng et al., 2000). After elevation of the intracellular $\mathrm{Ca}^{2+}$ concen- 


\section{Milk fever cows could stand within 1 day after a single $\mathrm{Ca}$ treatment (Group A) \\ vS. \\ Clinically healthy parturient cows \\ (Group C)}

Milk fever cows could stand within 1 day after a single Ca treatment (Group A)

vs.

Milk fever cows requiring further treatment after 1 day (Group B)

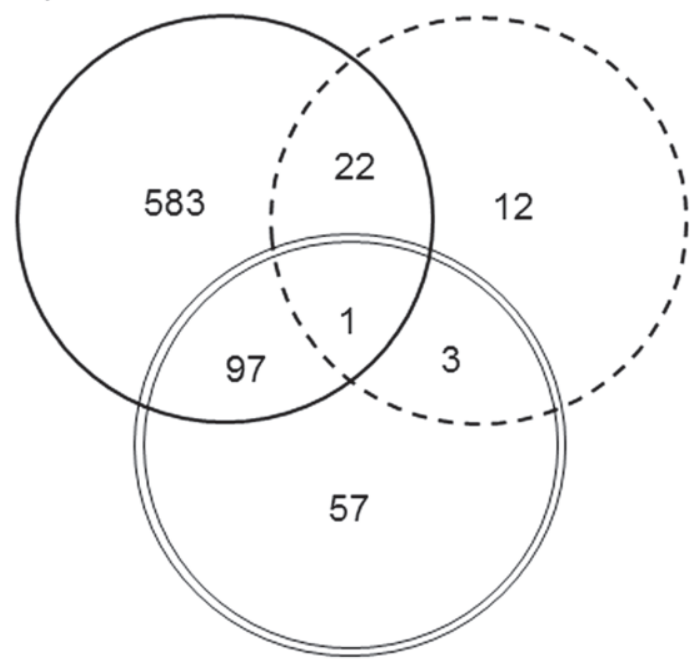

\section{Milk fever cows requiring further treatment after 1 day (Group B) \\ VS. \\ Clinically healthy parturient cows \\ (Group C)}

Figure 2. Venn diagram of the number of genes differentially expressed among the 3 groups: milk fever (groups A and B) and clinically healthy parturient cows (group C). The single solid-line circle represents 703 genes differentially expressed between groups A and C (group A vs. group C). The double solid-line circle represents 158 genes differentially expressed between groups B and C (group B vs. group C). Expressions of 98 genes were common to both circles. Of these 98 genes, one showed differential expression between Groups A and B (dashed-line circle, group A vs. group B).

tration, $\mathrm{Ca}^{2+}$ release from endoplasmic reticulum occurs by the action of inositol-1,4,5-triphosphate (IP3) binding to IP3 receptors on the endoplasmic reticulum membrane (Guse et al., 1993; Oh-hora and Rao, 2008). Phosphorylation of the IP3 receptor by PKA augments $\mathrm{Ca}^{2+}$ release (Foskett et al., 2007). Therefore, our data suggest that milk fever has a negative effect on $\mathrm{Ca}^{2+}$ release from the endoplasmic reticulum in PBMC due to hypocalcemia, as reported previously (Kimura et al., 2006).

DNA-damage-inducible transcript 4 (DDIT4, also known as REDD1) was originally identified to be transcriptionally upregulated in response to a variety of cellular stresses, including hypoxia (Brugarolas et al., 2004) or DNA-damaging agents (Lin et al., 2005). It is a stress-induced negative regulator of the mammalian target of rapamycin (mTOR) signaling pathway that regulates cell cycle progression, growth, and metabolism homeostasis; protein synthesis; ribosome biogenesis; the actin cytoskeleton; and autophagy (Foster and Fingar, 2010; Lisse et al., 2011). Period homolog 1 (PER1) is an important core clock gene that regulates normal cell proliferation and physiological rhythms (Gery et al., 2006; Zhao et al., 2013). Dexamethasone, a synthetic glucocorticoid that represses protein synthesis, was recently shown to upregulate the expression of DDIT1 in both lymphoid and nonlymphoid cells (Wang et al., 2006). Another study reported that intramuscular administration of dexamethasone to steers induces elevated plasma cortisol concentrations and PER1 mRNA level in neutrophils and lymphocytes (Nebzydoski et al., 2010). It is well known that plasma cortisol concentrations are elevated in both experimentally induced hypocalcemic cows and naturally occurring milk fever cases (Riond et al., 1999; Horst and Jørgensen, 1982). Therefore, the increased mRNA expressions of DDIT4 and PER1 described here were likely the result of glucocorticoid responsiveness due to hypocalcemia and milk fever.

The NUAK family, SNF1-like kinase, 1 (NUAK1), also known as AMP-activated protein kinase related kinase 5 (ARK5), is involved in cellular senescence, mo- 
Table 4. Microarray data of 98 genes whose expression in peripheral blood mononuclear cells of spontaneous milk fever cows (groups A and B) was significantly different from that in clinically healthy parturient cows (group C)

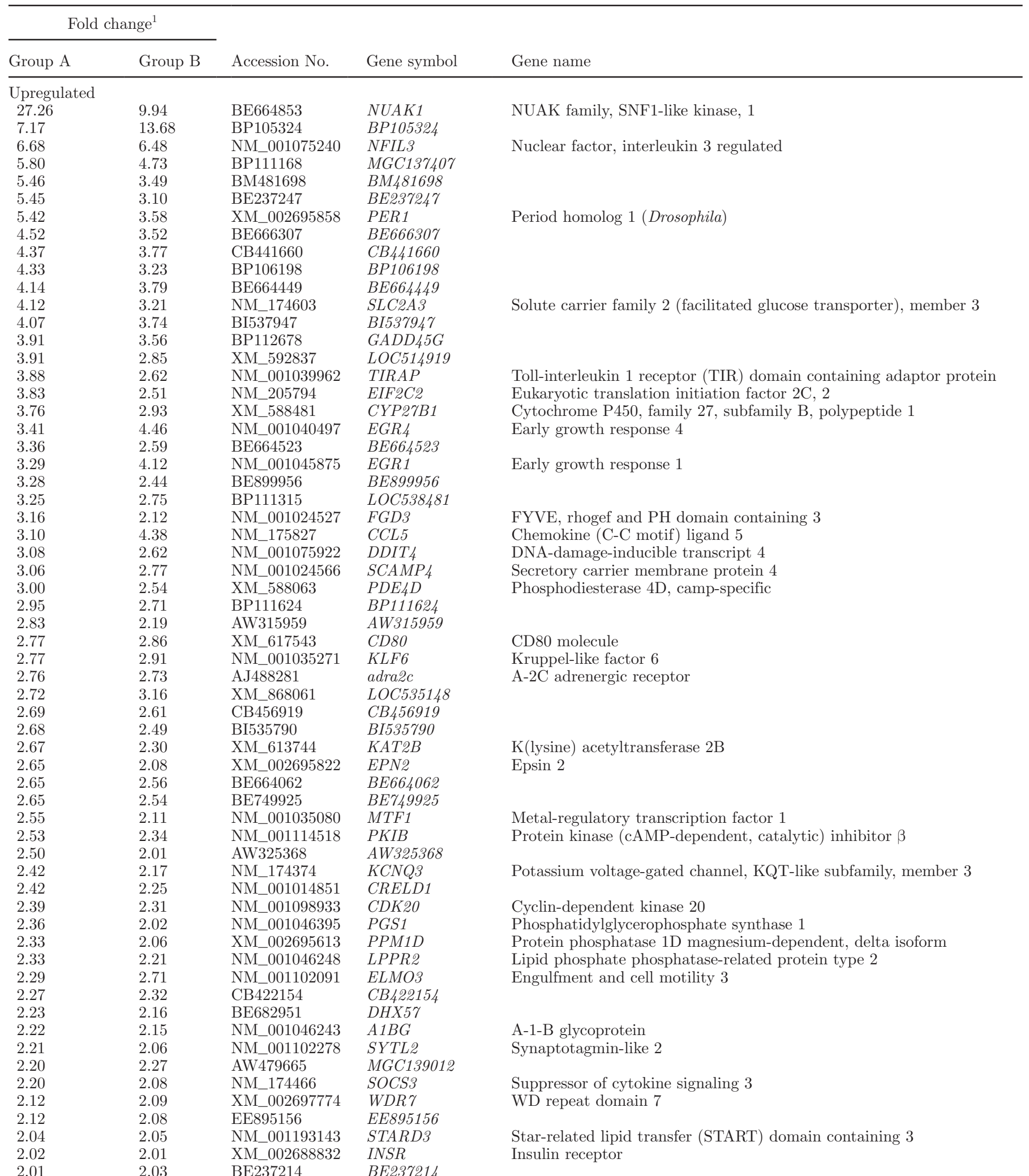


Table 4 (Continued). Microarray data of 98 genes whose expression in peripheral blood mononuclear cells of spontaneous milk fever cows (groups A and B) was significantly different from that in clinically healthy parturient cows (group C)

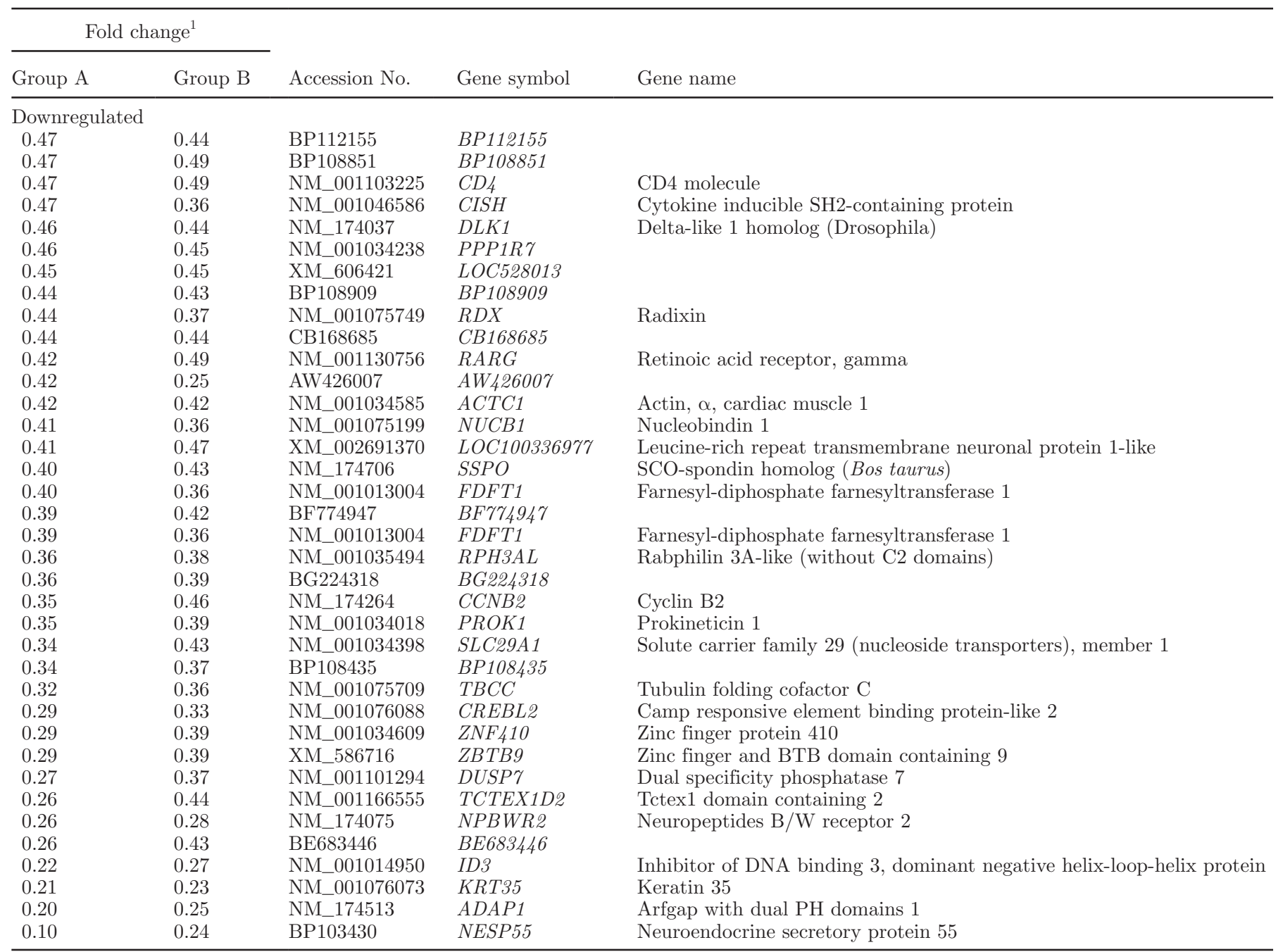

${ }^{1}$ Fold change in gene expression relative to that of group C.

tility, or proliferation of cultured cells; embryonic development; and cancer progression (Niesler et al., 2007; Humbert et al., 2010; Zagórska et al., 2010; Zungu et al., 2011). In tissues of adult humans, NUAK1 mRNA expression has been detected in the heart, brain, skeletal muscle, kidney, and ovary, but not in the liver, pancreas, lung, or intestine (official data are available on the KAZUSA DNA Research Institute homepage: http:// www.kazusa.or.jp/huge/gfpage/KIAA0537/). A recent study showed that a physiological role of NUAK1 is to suppress glucose uptake through negative regulation of insulin signaling in the soleus muscle of rats (Inazuka et al., 2012). Lymphocytes require tight regulation of glucose uptake to maintain immune homeostasis (MacIver et al., 2008), and cows with milk fever show increased plasma glucose concentrations associated with reduced secretion of insulin due to hypocalcemia (Larsen et al.,
2001). To date, little information on the physiological role of NUAK1 on PBMC accompanied by the effects of plasma glucose or insulin is available. Further study is needed to determine the cause of the upregulated NUAK1 mRNA expression in the PBMC of cows with experimental hypocalcemia and milk fever.

The function of BI537947 remains unclear. A gene expression analysis profile extracted from an expressed sequence tag database has provided important clues regarding the pathophysiological process of disease and the prediction of its clinical behavior (Krizman et al., 1999; Kim et al., 2006).

Interestingly, the microarray data demonstrated that NESP 55 mRNA level was altered in milk fever, and showed significant differences among treated milk fever cows. Expression of NESP55 mRNA showed different responses to the first $\mathrm{Ca}$ treatment (groups $\mathrm{A}$ and 
Milk fevervs. Healthy parturient cows

Experimental hypocalcemia

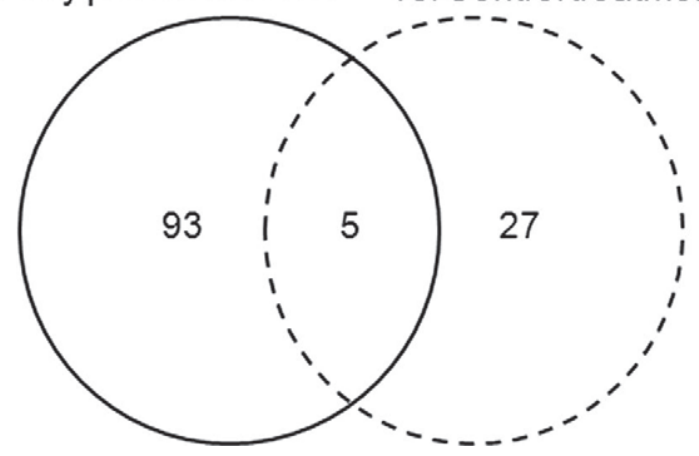

Figure 3. Venn diagram of the number of genes differentially expressed between the experimental hypocalcemia and milk fever groups. The solid-line circle (milk fever vs. healthy parturient cows) represents the 98 genes differentially expressed between milk fever (groups A and B) and clinically healthy parturient (group C) cows. The dashedline circle (experimental hypocalcemia vs. control treatment) represents 32 genes whose expression was significantly different between $\mathrm{Na}_{2}$-EDTA-induced hypocalcemia (hypocalcemic treatment) and CaEDTA-infused control (control treatment) cows. Expression of 5 genes was common to both circles.
B) and healthy parturient (group C) cows, although this gene was not specific to experimental hypocalcemia. However, q-PCR revealed that expression of this gene was significantly downregulated in both groups A and B compared with group C. Neuroendocrine secretory protein 55 (NESP55) was originally described as a chromogranin-like protein in secretory vesicles of adrenal chromaffin cells (Oczkowicz et al., 2012). In cattle, NESP 55 mRNA has been detected in many tissues (Khatib, 2004). The function of NESP55 remains unclear despite intensive investigation (Oczkowicz et al., 2012), although the application of this protein as a marker of neuroendocrinological tumor development in humans has been examined (Gupta et al., 2011). Validation of the alterations in NESP55 mRNA expression will be necessary for its use as a biomarker of milk fever independently of hypocalcemia.

In summary, the present study is the first microarray-based investigation to show altered mRNA levels of 6 genes in PBMC of cows with milk fever. Parturient dairy cows suffer immune suppression as well as mod-
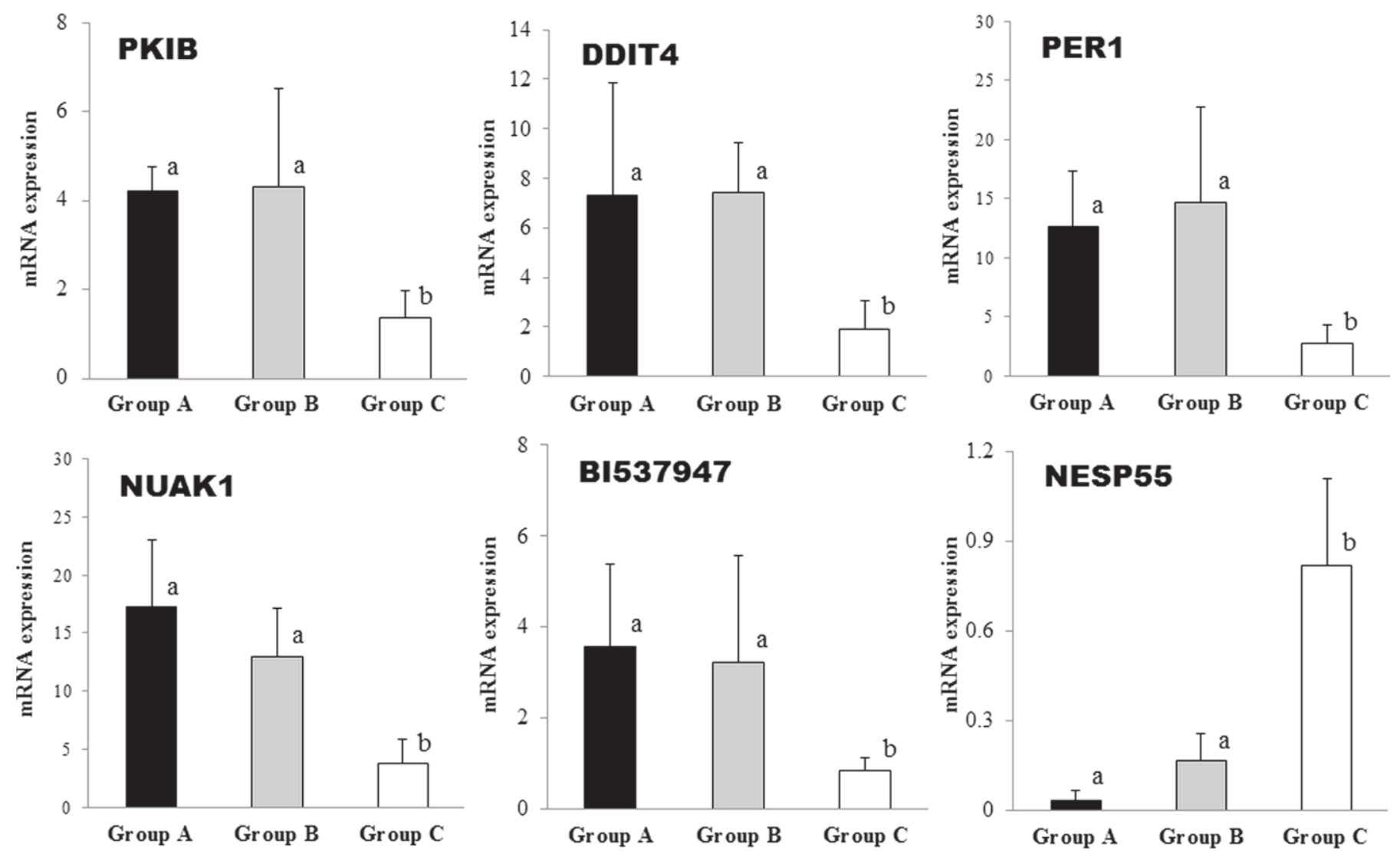

Figure 4. Real-time reverse transcription-PCR results of mRNA expression of the PER1, PKIB, DDIT4, NUAK1, BI537947, and NESP55 genes (Table 1) in peripheral blood mononuclear cells of milk fever (groups A and B) and clinically healthy parturient (group C) cows. All values were normalized to GAPDH mRNA. Different letters $(\mathrm{a}, \mathrm{b})$ indicate significant differences among the groups $(P<0.05)$. 
erate-to-severe hypocalcemia (Reinhardt et al., 1988), and epidemiological evidence shows that hypocalcemic cows are more susceptible to infectious disease (Curtis et al., 1983). Therefore, the altered mRNA expression of the genes described herein may be related to immune suppression due to decreased intracellular $\mathrm{Ca}^{2+}$ stores in PBMC (Kimura et al., 2006). In contrast, recent gene expression studies suggest that the expression profiles of circulating leukocytes exhibit specific expression signatures in response to various physiological, pathological, and environmental changes (Bull et al., 2004; Chon et al., 2004; Almeida et al., 2007). Circulating leukocytes express a large proportion of the total genes in the genome, which respond to changes in the macroand microenvironment in the body (Liew et al., 2006). The continuous interactions between blood cells and the entire body suggest that subtle intra- and extracellular changes in association with disease trigger specific micro-level changes in gene expression within blood cells (Liew et al., 2006). Therefore, the genes evaluated here could function as "sentinels" that respond to hypocalcemia and milk fever. However, before any genomic biomarkers are incorporated into clinical evaluation of milk fever, the effect of hypocalcemia on the mRNA expression of these genes in the tissues that regulate $\mathrm{Ca}$ homeostasis in dairy cows should be determined. The present data were obtained from comparisons of milk fever in "lactating" cows with experimentally induced hypocalcemia in "nonlactating" cows. Therefore, further study is needed to evaluate the effects of lactation on the PBMC expression because the mammary gland is involved in regulation of $\mathrm{Ca}$ homeostasis by secretion of a hormone that mobilizes Ca from the bone (Filipović et al., 2008).

\section{CONCLUSIONS}

This oligo-microarray analysis revealed that 32 genes in PBMC of cows with experimentally induced hypocalcemia were significantly up- or downregulated compared with cows that underwent control treatment. In cows with milk fever, 98 genes were expressed differentially (up- or downregulated) compared with healthy parturient cows. Five genes [PKIB, DDIT4, PER1, NUAK1, and EST (BI537947)] were strongly related to both experimental hypocalcemia and milk fever. Another gene, NESP55, was determined to be specific to milk fever, independently of hypocalcemia. The mRNA levels of these 6 genes in cows with milk fever were verified by quantitative real-time reverse transcription PCR, and were again shown to be significantly different from those in healthy parturient cows. The selected genes described herein represent candidate specific genomic biomarkers of milk fever, because the continuous interactions between blood cells and the entire body suggest subtle intracellular changes in association with disease.

\section{REFERENCES}

Almeida, P. E., P. S. D. Weber, J. L. Burton, R. J. Tempelman, J. P. Steibel, and A. J. Zanella. 2007. Gene expression profiling of peripheral mononuclear cells in lame dairy cows with foot lesions. Vet. Immunol. Immunopathol. 120:234-245.

Brown, E. M., M. Pollak, Y. H. Chou, C. E. Seidman, J. G. Seidman, and S. C. Hebert. 1995. Cloning and functional characterization of extracellular $\mathrm{Ca}^{2+}$-sensing receptors from parathyroid and kidney. Bone 17:7-11.

Brugarolas, J., K. Lei, R. L. Hurley, B. D. Manning, J. H. Reiling, E. Hafen, L. A. Witters, L. W. Ellisen, and W. G. Kaelin Jr. 2004. Regulation of mTOR function in response to hypoxia by REDD1 and the TSC1/TSC2 tumor suppressor complex. Genes Dev. 18:2893-2904.

Bull, T. M., C. D. Coldren, M. Moore, S. M. Sotto-Santiago, D. V. Pham, S. P. Nana-Sinkam, N. F. Voelkel, and M. W. Geraci. 2004 Gene microarray analysis of peripheral blood cells in pulmonary arterial hypertension. Am. J. Respir. Crit. Care Med. 170:911919.

Chon, H., C. A. Gaillard, B. B. van der Meijden, H. M. Dijstelbloem, R. J. Kraaijenhagen, D. van Leenen, F. C. Holstege, J. A. Joles, H. A. Bluyssen, H. A. Koomans, and B. Braam. 2004. Broadly altered gene expression in blood leukocytes in essential hypertension is absent during treatment. Hypertension 43:947-951.

Curtis, C. R., H. N. Erb, C. J. Sniffen, R. D. Smith, P. A. Powers, M. C. Smith, M. E. White, R. B. Hillman, and E. J. Pearson. 1983. Association of parturient hypocalcemia with eight periparturient disorders in Holstein cows. J. Am. Vet. Med. Assoc. 183:559-561.

Devkota, B., K. Itagaki, D. Kim, K. Sasaki, T. Osawa, K. Furuhama, and N. Yamagishi. 2012. Relationship between sex hormone fluctuations and biomarkers of bone resorption in bovine plasma during the oestrous cycle. Vet. J. 194:256-258.

Filipović, N., Z. Stojević, M. Zdelar-Tuk, and V. Kusec. 2008. Plasma parathyroid hormone-related peptide and bone metabolism in periparturient dairy cows. Acta Vet. Hung. 56:235-244.

Foskett, J. K., C. White, K. H. Cheung, and D. O. Mak. 2007. Inositol trisphosphate receptor $\mathrm{Ca}^{2+}$ release channels. Physiol. Rev. $87: 593-658$.

Foster, K. G., and D. C. Fingar. 2010. Mammalian target of rapamycin (mTOR): Conducting the cellular signaling symphony. J. Biol. Chem. 285:14071-14077.

Gascon-Barré, M., P. Haddad, S. J. Provencher, S. Bilodeau, F. Pecker, S. Lotersztajn, and S. Vallières. 1994. Chronic hypocalcemia of vitamin $\mathrm{D}$ deficiency leads to lower intracellular calcium concentrations in rat hepatocytes. J. Clin. Invest. 93:2159-2167.

Gery, S., N. Komatsu, L. Baldjyan, A. Yu, D. Koo, and H. P. Koeffler. 2006. The circadian gene per1 plays an important role in cell growth and DNA damage control in human cancer cells. Mol. Cell $22: 375-382$.

Ginsburg, G. S., and S. B. Haga. 2006. Translating genomic biomarkers into clinically useful diagnostics. Expert Rev. Mol. Diagn. 6:179-191.

Goff, J. P. 2008. The monitoring, prevention, and treatment of milk fever and subclinical hypocalcemia in dairy cows. Vet. J. 176:50-57.

Goff, J. P. 2009. Calcium, magnesium, and phosphorus. Pages 1369 1377 in Large Animal Internal Medicine. 4th ed. B. P. Smith, ed. Mosby, St. Louis, MO.

Gupta, M., R. V. Lloyd, R. Fischer-Colbrie, A. S. Tischler, and Y. Dayal. 2011. Immunohistochemical expression of neuroendocrine secretory protein-55 (NESP-55) in pituitary adenomas. Endocr. Pathol. 22:150-154.

Guse, A. H., E. Roth, and F. Emmrich. 1993. Intracellular $\mathrm{Ca}^{2+}$ pools in Jurkat T-lymphocytes. Biochem. J. 291:447-451.

Horst, R. L., J. P. Goff, and T. A. Reinhardt. 1994. Calcium and vitamin D metabolism in the dairy cows. J. Dairy Sci. 77:1936-1951. 
Horst, R. L., J. P. Goff, T. A. Reinhardt, and D. R. Buxton. 1997. Strategies for preventing milk fever in dairy cattle. J. Dairy Sci. 80:1269-1280.

Horst, R. L., and N. A. Jørgensen. 1982. Elevated plasma cortisol during induced and spontaneous hypocalcemia in ruminants. J. Dairy Sci. 65:2332-2337.

Humbert, N., N. Navaratnam, A. Augert, M. Da Costa, S. Martien, J. Wang, D. Martinez, C. Abbadie, D. Carling, Y. de Launoit, J. Gil, and D. Bernard. 2010. Regulation of ploidy and senescence by the AMPKrelated kinase NUAK1. EMBO J. 29:376-386.

Inazuka, F., N. Sugiyama, M. Tomita, T. Abe, G. Shioi, and H. Esumi 2012. Muscle-specific knock-out of NUAK family SNF1-like kinase 1 (NUAK1) prevents high fat diet-induced glucose intolerance. J. Biol. Chem. 287:16379-16389.

Ishida, S., T. Yonezawa, S. Eirai, K. Kizaki, K. Hashizume, M. Tomioka, Y. Kurose, T. Hirano, and D. Watanabe. 2013. Hormonal differences in peripheral blood and gene profiling in the liver and lymphocytes in Japanese black cattle with growth retardation. J. Vet. Med. Sci. 75:17-25.

Jørgensen, R. J., N. R. Nyengaard, R. C. Daniel, L. S. Mellau, and J. M. Enemark. 1999. Induced hypocalcaemia by $\mathrm{Na}_{2}$ EDTA infusion. A review. Zentralbl. Veterinarmed. A 46:389-407.

Khatib, H. 2004. Imprinting of Nesp55 gene in cattle. Mamm. Genome 15:663-667.

Kim, D., N. Yamagishi, A. Ueki, M. Miura, F. Saito, S. Sato, and K. Furuhama. 2010. Changes in plasma bone metabolic markers in periparturient dairy cows. J. Vet. Med. Sci. 72:773-776.

Kim, J. M., K. H. Lee, Y. J. Jeon, J. H. Oh, S. Y. Jeong, I. S. Song, J. M. Kim, D. S. Lee, and N. S. Kim. 2006. Identification of genes related to Parkinson's disease using expressed sequence tags. DNA Res. 13:275-286.

Kimura, K., T. A. Reinhardt, and J. P. Goff. 2006. Parturition and hypocalcemia blunts calcium signals in immune cells of dairy cattle. J. Dairy Sci. 89:2588-2595.

Kizaki, K., A. Shichijo-Kizaki, T. Furusawa, T. Takahashi, M. Hosoe, and K. Hashizume. 2013. Differential neutrophil gene expression in early bovine pregnancy. Reprod. Biol. Endocrinol. 11:6. http:// dx.doi.org/10.1186/1477-7827-11-6.

Krizman, D. B., L. Wagner, A. Lash, R. L. Strausberg, and M. R. Emmert-Buck. 1999. The cancer genome anatomy project: EST sequencing and the genetics of cancer progression. Neoplasia $1: 101-106$.

Larsen, T., G. Møller, and R. Bellio. 2001. Evaluation of clinical and clinical chemical parameters in periparturient cows. J. Dairy Sci. $84: 1749-1758$.

Liesegang, A., M. L. Sassi, J. Risteli, R. Eicher, M. Wanner, and J. L. Riond. 1998. Comparison of bone resorption markers during hypocalcemia in dairy cows. J. Dairy Sci. 81:2614-2622.

Liew, C. C., J. Ma, H. C. Tang, R. Zheng, and A. A. Dempsey. 2006. The peripheral blood transcriptome dynamically reflects system wide biology: A potential diagnostic tool. J. Lab. Clin. Med. 147:126-132.

Lin, L., Y. Qian, X. Shi, and Y. Chen. 2005. Induction of a cell stress response gene RTP801 by DNA damaging agent methyl methanesulfonate through CCAAT/enhancer binding protein. Biochemistry 44:3909-3914.

Lisse, T. S., T. Liu, M. Irmler, J. Beckers, H. Chen, J. S. Adams, and M. Hewison. 2011. Gene targeting by the vitamin D response element binding protein reveals a role for vitamin D in osteoblast mTOR signaling. FASEB J. 25:937-947.

Livak, K. J., and T. D. Schmittgen. 2001. Analysis of relative gene expression data using real-time quantitative PCR and the $2^{-\triangle \Delta C T}$ method. Methods 25:402-408.

Loor, J. J., R. E. Everts, M. Bionaz, H. M. Dann, D. E. Morin, R. Oliveira, S. L. Rodriguez-Zas, J. K. Drackley, and H. A. Lewin. 2007. Nutrition-induced ketosis alters metabolic and signaling gene networks in liver of periparturient dairy cows. Physiol. Genomics 32:105-116.

Lutzow, Y. C. S., L. Donaldson, C. P. Gray, T. Vuocolo, R. D. Pearson, A. Reverter, K. A. Byrne, P. A. Sheehy, R. Windon, and R. L. Tellam. 2008. Identification of immune genes and proteins involved in the response of bovine mammary tissue to Staphylococcus aureus infection. BMC Vet. Res. 4:18-25.

MacIver, N. J., S. R. Jacobs, H. L. Wieman, J. A. Wofford, J. L. Coloff, and J. C. Rathmell. 2008. Glucose metabolism in lymphocytes is a regulated process with significant effects on immune cell function and survival. J. Leukoc. Biol. 84:949-957.

Mailhot, G., J. L. Petit, C. Demers, and M. Gascon-Barré. 2000. Influence of the in vivo calcium status on cellular calcium homeostasis and the level of the calcium-binding protein calreticulin in rat hepatocytes. Endocrinology 141:891-900.

Mellau, L. S., R. J. Jørgensen, P. C. Bartlett, J. M. Enemark, and A. K. Hansen. 2004. Effect of anionic salt and highly fermentable carbohydrate supplementations on urine $\mathrm{pH}$ and on experimentally induced hypocalcaemia in cows. Acta Vet. Scand. 45:139-147.

Morris, D. D. 2009. Alterations in the leukogram. Pages $405-410$ in Large Animal Internal Medicine. 4th ed. B. P. Smith, ed. Mosby, St. Louis, MO.

Nebzydoski, S. J., S. Pozzo, L. Nemec, M. K. Rankin, and T. F. Gressley. 2010. The effect of dexamethasone on clock gene mRNA levels in bovine neutrophils and lymphocytes. Vet. Immunol. Immunopathol. 138:183-192.

Newman, J. H., T. N. Holt, L. K. Hedges, B. Womack, S. S. Memon, E. D. Willers, L. Wheeler, J. A. Philips III, and R. Hamid. 2011. High-altitude pulmonary hypertension in cattle (brisket disease): Candidate genes and gene expression profiling of peripheral blood mononuclear cells. Pulm. Circ. 1:462-469.

Niesler, C. U., K. H. Myburgh, and F. Moore. 2007. The changing AMPK expression profile in differentiating mouse skeletal muscle myoblast cells helps confer increasing resistance to apoptosis. Exp. Physiol. 92:207-217.

Oczkowicz, M., A. Piestrzyńska-Kajtoch, K. Ropka-Molik, B. Rejduch, and R. Eckert. 2012. Expression and imprinting analysis of the NESP 55 gene in pigs. Gene Expr. Patterns 12:18-23.

Oh-hora, M., and A. Rao. 2008. Calcium signaling in lymphocytes. Curr. Opin. Immunol. 20:250-258.

Reinhardt, T. A., R. L. Horst, and J. P. Goff. 1988. Calcium, phosphorus, and magnesium homeostasis in ruminants. Vet. Clin. North Am. Food Anim. Pract. 4:331-350.

Riond, J. L., A. Liesegang, M. Wanner, C. Kaiser, M. Döbeli, and H. I. Joller-Jemelka. 1999. Effects of EDTA-induced hypocalcaemia and stress on plasma TNF-alpha, IL-1-ra, G-CSF, GM-CSF and S-100 in dairy cows. Vet. Res. Commun. 23:299-306.

Robinson, T. L., I. A. Sutherland, and J. Sutherland. 2007. Validation of candidate bovine reference genes for use with real-time PCR. Vet. Immunol. Immunopathol. 115:160-165.

Sasaki, K., K. Sasaki, Y. Sato, B. Devkota, K. Furuhama, and N. Yamagishi. 2013. Response of Holstein cows with milk fever to first treatment using two calcium regimens: A retrospective clinical study. J. Vet. Med. Sci. 75:373-376.

Wang, H., N. Kubica, L. W. Ellisen, L. S. Jefferson, and S. R. Kimball. 2006. Dexamethasone represses signaling through the mammalian target of rapamycin in muscle cells by enhancing expression of REDD1. J. Biol. Chem. 281:39128-39134.

Zagórska, A., M. Deak, D. G. Campbell, S. Banerjee, M. Hirano, S. Aizawa, A. R. Prescott, and D. R. Alessi. 2010. New roles for the LKB1-NUAK pathway in controlling myosin phosphatase complexes and cell adhesion. Sci. Signal. 3:ra25.

Zhao, N., K. Yang, G. Yang, D. Chen, H. Tang, D. Zhao, and C. Zhao. 2013. Aberrant expression of clock gene period1 and its correlations with the growth, proliferation and metastasis of buccal squamous cell carcinoma. PLoS ONE 8:e55894.

Zheng, L., L. Yu, Q. Tu, M. Zhang, H. He, W. Chen, J. Gao, J. Yu, Q. Wu, and S. Zhao. 2000. Cloning and mapping of human PKIB and PKIG, and comparison of tissue expression patterns of three members of the protein kinase inhibitor family, including PKIA. Biochem. J. 349:403-407.

Zungu, M., J. C. Schisler, M. F. Essop, C. McCudden, C. Patterson, and M. S. Willis. 2011. Regulation of AMPK by the ubiquitin proteasome system. Am. J. Pathol. 178:4-11. 